and temperature, this relation does not hold for the yearly means; that is to say, it does not follow that a high yearly mean pressure should indicate a low yearly mean temperature, and vice versî.

We may, however, arrive at a satisfactory answer to the original question by an examination of the variations of yearly mean temperature at the different stations. It must be remembered that the relation of the oscillations of monthly mean pressure to those of monthly mean cemperature are deduced from the variations shown by a thermometer four or five feet from the ground. Does the thermometer at any station, or at a combination of stations, show a high yearly mean temperature with a low yearly mean pressure, and vice versâ? I have given the variations of yearly mean temperature $(\Delta T)$ at different stations, and it requires only a cursory examination of them to see that there is no such relation. There is, however, another fact of very great importance to be deduced from the values of $\Delta \mathrm{T}$, and that is, the very great constancy of the yearly mean temperature at all the stations, in spite of the known considerable variations in the amount of rain and of other meteorological results from year to year.

It may be asked how we can explain the facts which seem to relate the annual oscillations of the mean pressure and mean temperature with the independence of the variations of the yearly means. As an illustration we can suppose that with a strong wind and high temperature the height of the tide may be increased at a certain port, while a following north wind with low temperatures will diminish the height at low water; we should in such a case, especially if the temperature varied with the force of the wind, have a larger oscillation of the water with a larger oscillation of temperature : we would not, however, attribute the high tide to the greater heat; we can also conceive that the mean temperature might, in the case supposed, vary, but the level of the ocean would remain constant. Other illustrations might be suggested.

The conclusions at which I have arrived are :-

I. That the years of greatest and least mean barometric pressure are probably the same for all India.

2. Therefore, that the apparent relation to the decennial period found by Mr. C. Chambers for Bombay holds for all India.

3. That the annual oscillations of monthly mean pressure and monthly mean temperature have nearly a constant ratio in India.

4. That these oscillations depend on local conditions in the same latitude, at places quite near each other, which are independent of the heat emitted by the sun.

5. That the yearly mean isobars run parallel to the equator in India and are independent of local conditions.

6. That the directions of the yearly mean isotherms vary with the local conditions.

7. That there is no relation between the variations of yearly mean temperature and yearly mean pressure. JOHN ALLAN BROUN

\section{THE SIZE OF THE TIGER}

$\mathrm{T} \mathrm{N}$ a work on the tiger, published in $1875,{ }^{1} \mathrm{I}$ made the following remarks in reference to the size of the animal :-

"The size of the tiger varies: some individuals attain great bulk and weight, though they are shorter than others which are of a slighter and more elongated form. The statements as to the length they attain are conflicting and often exaggerated; errors are apt to arise from measurements taken from the skin after it is stretched, when it may be 1o or 12 inches longer than before semoval from the body. The tiger should be measured from the nose along the spine to the tip of the tail as he

\footnotetext{
I Royal Tiger of Bengal, pp. 29, 30.
}

lies dead on the spot where he fell before the skin is removed. One that is io feet by this measurement is large, and the full-grown male does not often exceed this, though no doubt larger individuals (males) are occasionally seen, and I have been informed by Indian sportsmen of reliability that they have seen and killed tigers over I2 feet in length. The full-grown male Indian tiger, therefore, may be said to be from 9 to 12 feet or 12 feet 2 inches, the tigress from 8 to ro or perhaps in very rare instances II fiet in length, the height being from 3 to $3 \frac{1}{2}$, or, rarely, 4 feet at the shoulder."

The point I now especially desire to elucidate as it has been the subject of discussion, but is one that has never yet been satisfactorily settled, is the greatest length the tiger attains.

Jerdon and others say that the average size of a fullgrown male tiger is from 9 to $9 \frac{1}{2}$ feet in length; and Jerdon remarks that he has not seen any authentic account of a tiger that measured more than ro feet and 2 or 3 inches.

I agree with Jerdon that 9 to $9 \frac{1}{2}$ or 10 and 2 or 3 inches are the lengths attained by the majority of tigers met with; but the occasional occurrence of tigers of upwards of ro feet 2 or 3 inches (the authenticity of which is doubted) is attested by the evidence of several competent and reliable observers, who are quite aware that the measurements should be those of the animal as he lies where he fell, and before being despoiled of his skin, and that measurements of the slin after removal are deceptive.

I have taken some pains to ascertain the views of those who are most likely to be well informed on the subject, and I add the results of my own observations during considerable experience in Bengal, Oude, and Nepal; it would seem that the evidence wanted by Jerdon is forthcoming, and that tigers above ro feet 3 inches, ir feet, and even $\mathrm{I} 2$ feet, are occasionally met with, and have been accurately neasured.

I may remark that it is very possible that like boars, and other animals, they may differ in size according to locality, food, and other conditions of life; and that such being the case, it is probable that tigers of one province or district may exceed those of another in size. Indeed I am inclined to believe that such is the case, and that therefore those who contend for the larger may be equally right with those who maintain the smaller measurements. I am rather inclined to agree with $\mathrm{Mr}$. C. Shillingford, who suggests the possible progressive degeneration of the tiger; what, certainly, according to some, obtains in the case of stags in the continuously over-shot deer forests of Scotland, may also be going on in the tiger of the much-hunted jungles of India. However this is a mere suggestion, but be it as it may, the inches of the big tiger are, I think, an ascertained fact, for it can hardly be maintained that the authorities who rouch for it are either mistaken or misinformed, or that they do not know how to measure a tiger accurately.

Sir G. Yule, K.C.S.I., Bengal Civil Service, says : "I never had the luck to fall in with a 12 -foot tiger; I I feet odd inches I have killed twice or thrice. I have heard once, at least, of a 12-foot fellow fairly measured, and I cannot see why there should be any doubt as to the occasional occurrence of such exceptions to the general rule."

Col. George Boileau, Bengal army, says he killed a tiger at Mutearah, in Oude, that was well over 12 feet. He writes:- "I can speak positively as to the size of the tiger-his length was well over i2 feet before the skin was removed. He was, of course, quite an exceptional size, and unequalled, so far as my own experience goes, which extended over seventeen years of constant hunting after the species. My own experience of the isize of tigers is that, in the female, the size runs from 8 feet to $9 \frac{1}{2}$ feet-the latter exceptionally large; in the male, from 9 feet to in feet; a well-grown adult tiger is 
seldom less than to feet in length. I speak of huntinggrounds frequented by myself (chiefly Oude and Nepal Terai), for no doubt the size varies according to locality, abundance of food, and its reverse must of course produce their usual results."

Col. Sleeman, Bengal army, says:--"I don't remember having killed a tiger measuring more than 10 feet 6 inches in his skin, but I have seen skins of tigers II feet 6 inches in length, and once, at Dinagepore, in Bengal, over 12 feet. I have the skin of the largest tiger I think I ever saw, and it measures 12 feet 2 inches. This tiger was killed near Jubbulpore, in Central India, by an old Thakoor sixty years of age, and I preserve the skin as a trophy of native pluck and vigour in age."

The skins above alluded to were, no doubt, stretched, and therefore do not prove more than that they were taken from large animals, which may have been probably between 10 and $I$ I feet in length !

Col. J. Macdonald, Bengal army, Revenue Survey, says:- "The largest tiger I have ever measured out of seventy was ro feet 4 inches, and out of all these only three have touched ro feet. But I do believe that tigers have exceptionally reached 12 feet." "The skin of a tiger ten feet in length, as he lies dead, would stretch to nearly twelve feet, but after curing it returns to nearly its normal size. I have often measured the distance between a tiger's marks on the ground; average and large animals are from 4 feet 4 inches to 4 feet 8 inches; well! I once found marks 5 feet 10 inches apart, this must have been the mark of a gigantic beast-the breadth of the impression of the fore paw, and the depth of the impression, showed his great size and weight. This was in the Sunderbunds. Mr. M., of Morel-Gunge, told me that once when going through a narrow creek in the Sunderbunds, he saw a stupendous brute, far exceeding in size anything he had before seen in tigers or could have believed possible. The heaviest male tiger I have seen weighed 448 lbs., the lightest, a tigress, 242 lbs."

The Hon. R. Drummond, B.C.S., late Commissioner, Rohilkund, says :-

"I have never seen a 12-foot tiger. The largest I ever shot was II feet 9 inches as he lay on the ground immediately he was shot, and before being padded. I mea sured him because I was struck with his large size."

F. B.Simson, Es7., B.C.S., says :- "I have killed or been at the death of about 180 tigers; I never actually handled one I 1 feet long, but I fully believe that they reach that length occasionally, and every now and then a monster is found. The largest skins by far I have seen, came from China. I give you the exact measurements of several I have killed and fairly measured immediately after death, and before they were padded with dates :-

\begin{tabular}{|c|c|c|c|c|c|c|c|c|c|}
\hline & & & & & igers & leag & & & He.ght \\
\hline & & & & & & In. & & & $\mathrm{Ft}$. \\
\hline & October & 15 & $\ldots$ & $\ldots$ & 9 & 5 & $\ldots$ & $\ldots$ & 3 \\
\hline & February & 13 & $\ldots$ & $\ldots$ & Io & 4 & $\ldots$ & $\ldots$ & 3 \\
\hline & & II & $\ldots$ & $\ldots$ & 10 & II & $\ldots$ & $\ldots$ & 3 \\
\hline 58 & March & 15 & $\ldots$ & $\ldots$ & 9 & I & $\ldots$ & $\ldots$ & \\
\hline & & & & & resse & ' Jen & & & \\
\hline 1855 & October & 14 & $\ldots$ & $\ldots$ & 8 & 8 & $\ldots$ & $\ldots$ & \\
\hline & , & 13 & $\ldots$ & $\ldots$ & 8 & 5 & $\ldots$ & $\ldots$ & 3 \\
\hline ", & & 19 & . & $\ldots$ & 8 & II & $\ldots$ & $\ldots$ & 3 \\
\hline & Noven & 22 & "n & $\ldots$ & 8 & 10 & $\ldots$ & $\ldots$ & 3 \\
\hline 1856 & October & 6 & $\ldots$ & $\ldots$ & 9 & 4 & $\ldots$ & $\ldots$ & 3 \\
\hline 1857 & February & 8 & $\ldots$ & $\ldots$ & 8 & Io & $\cdots$ & $\cdots$ & 3 \\
\hline
\end{tabular}

"All these were killed on the churs of the Megna, between Backergunge and Noakhally. In later years I killed tigers in Purneah, Docca, Mymensingh, and Assam, but their exact dimensions were not recorded. I do not remember any exceeding generally in size the measurenents I have given. I once killed a tiger which stood almost 4 feet at the shoulder.

"I have often been referred to about hogs. I have taken about 900 first spears, and hunted in nearly every zillah in Bengal, but I never speared the boar that would not have walked under a standard of 3 feet 3 inches, This statement has disappointed many; but the facts are at your service, and you may use my name to authenticate them when you choose."

Major-General Sir H. Green, K.C.S.I., C.B., Bombay, says:-"The biggest tiger I was ever at the killing of was in 1848, near Surat, and it measured, pegged out, 12 feet 4 inches. I heard by last mail from Claude Clerk at Hyderabad, who said he had just killed, to his own gun, the biggest tiger he had ever seen, as it measured 11 feet 6 inches before skinning."

Sir H. Green also writes:- "I inclose a letter from Col. Stewart regarding tigers, and I have made many inquiries about them since, and there can be no doubt that a 12-foot tiger is very rare, although I have no doubt there are instances of that size having been exceeded. I find, by reference to my journal, that I have a record of some I have killed, and that the one I mentioned as I 2 feet 4 inches, pegged out, measured, before skinning, $\mathrm{I}$ f feet $\mathrm{I} I$ inches. Measures before skinning :-

II feet II inches.

I0 ", II ,

9 ", 9 ,"

$9, " 6, ", \quad$.

$9, " 3$

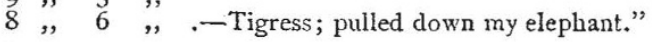

Col. D. G. Stewart writes :- "I have never seen or heard of a bona fide $\mathrm{I} 2$-foot tiger, i.e., as he lay in his skin. The largest I ever saw or killed was, as he lay, II feet and $\frac{1}{4}$ inch. I bave personally measured eighty tigers or more of my own shooting, and the dimensions $I$ have given are those of the largest of my victims. I saw a skin in San Francisco, of a Chinese tiger, which might have been 12 feet long in life. I never saw anything Indian to approach it. The Chinese skin was fairly treated, had breadth as well as length, the fur was long and soft. The average size of large males in the Central Provinces I found to be Io feet 6 inches to ro feet 8 inches; the tail had a good deal to do with the last two or three inches. The largest tigress I killed was, I think, 9 feet 3 or 4 inches, but I speak from memory. Of two males the girth of the fore-arm of one was 48 inches, the average being 32 to 34 inches. One of the most remarkable measurements is that of the tail where it joins the carcass. I have repeatedly found it in males 12 inches.?

The Hon. Sir H. Ramsay, K.C.S.I., C.B., Commissioner, Kumaon, writes: "I have always understood that Bengal tigers are larger than ours in the north-west. The largest tiger I ever killed measured ro feet 5 inches, and I consider anything above ro feet a large tiger; a tigress very seldom gets beyond 9 feet. I have heard of Bengal tigers measur ing i 2 feet. $G$. tells me his father, a Bengal civilian, shot a tiger that measured 12 feet 4 inches, but I never shot in Bengal."

Mr. C. Shillingford, indigo-planter, Purneah (with whom I have shot many tigers) says: "My experience extends over thirty-five years, during which I have shot more than 200 tigers. In 1849 I shot one of the largest tigers I have ever seen, with a party of four. $\mathrm{He}$ measured, as he fell, 12 feet 4 inches, was very old, and his marks had become faint; the hair was short, like that of a greyhound. I shot another tiger which measured, as he fell II feet 10 inches, and another in 1855 , I I feet 4 inches; several of ro feet 6 inches and ro feet. The majority of male tigers seldom exceed 10 feet, and many attain only 9 feet 8 inches or 9 feet ro inches.'

Cumming says he has shot a few over I I feet, and gives three instances-one at Rohinipore, II feet 4 inches: one at Kaliastrich in 1865 , of 1 I feet 2 inches; and another at Gour in 1871. My nephew has also shot one or two over II feet.

I think these very large tigers are rare, and are only to be found in the Ganges churs; I am also inclined to believe 
that they are degenerating, as I have not shot large ones for several years: or it may be that there is a keener set of sportsmen now-a-days, and no sooner is a tiger heard of than he is shot. The tigresses are seldom over 8 feet, though I have known some that attained 9 feet to 9 feet 6 inches. Cumming says he has seen the claw-marks of a tiger on a tree 18 feet high. The men who are difficult to convince about the large tigers are those who have shot them in hills and rocky places, and those tigers are of a different class and seldom grow large."

Major Bradford, C.S.I., of the Political Service, says: " 10 feet 5 inches was the largest tiger I ever saw; but I sent the question to Martin and inclose his reply and the inclosures to it. I remember hearing of the immense tiger White speaks of."

Col. C. Martin, C.I. Horse, says he shot a tiger at Putulghur ro feet in length, and alludes to a large tiger shot near Goona by Mr. White, which was measured by Mr. Angelo, and is described as follows by the latter gentleman: "I can remember, beyond all doubt, the length was 12 feet 4 inches from tip of nose to tip of tail ; 2 feet 2 inches from ear to ear! The direct breadth of wrist 8 inches, spread of foot 10 inches, heel to withers 4 feet, and the tail was 3 feet in length."

These measurements were recorded in the Delhi Gazette, but there is some doubt as to their accuracy; so that they may bardly be regarded as proving more than that the tiger was a very large one. Col. Martin says, iin a subsequent letter, "W.'s tiger, which I had always thought 12 feet 4 inches, is no longer to be relied on for scientific inquiry, though it probably exceeded ro feet."

Lieut. James Ferris, B. Army, says: "I have had a good deal of experience, as I have shot in the Central Provinces, and for several years in Oude and Nepal. The largest tiger I know of was shot by Wilkinson, in 1873 , in Nepal, he measured to feet 4 inches from tip of nose to tip of tail. Wilkinson, who has shot more tigers than most men in India, told me this was the largest he had ever seen; the largest tiger I ever shot myself I got the same season in Nepal; he measured Io feet 2 inches - - he was considered a monster. The tigers in Lower Bengal may be larger, but in the Central Provinces they are certainly smailer; it depends a great deal on how the tiger is measured.'

Gen. Ramsay, Bengal Army, says : "The largest tiger $I$ ever saw I shot in conjunction with Col. Stewart, a fine old sportsman, who died many years ago at Benares. The tiger was not found for some days, when he was discovered dying from loss of blood and starvation. The skin was remored, and measured 12 feet from the nose to end of tail." This skin was no doubt stretched. "A tiger of 10 feet 6 inches is a very fair sized tiger. Tigresses seldom grow so large." General Ramsay adds: "My friend Col. H. Shakspeare writes me that 'the two largest tigers he ever killed were, when brought in and measured, I I feet 8 inches and in feet 6 inches respectively-the latter a tigress.' He does not think he has ever seen larger ones. There probably are tigers that measure 12 feet or more, but they would be very rare."

Mr. F. Buckland has kindly given me the following extract from his "Curiosities," 1866 , in regard to a tiger shot by Col. Ramsay, who says that he and Major B. shot a tiger at Huldwana, in the Kumaon Terai, that they estimated to be about twelve years of age, and was of the following dimensions:-

Length from nose to end of tail

ft. in.

," of tail

Height from heel to shoulder $\ldots$

Girth of body behind shoulder... forearm " neck

From ear to ear ...

Length of upper canines

$\begin{array}{ll}, & \text { lower , } \\ , & \text { claws ... }\end{array}$
On referring to some of my own tiger shooting notes I find that I have recorded the following measurements:Oude Terai, 1855

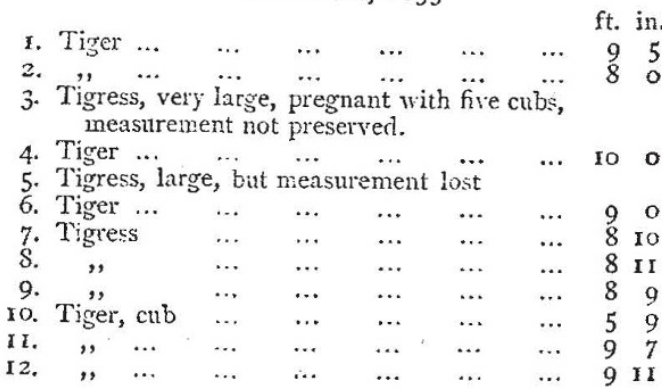

Outie Terai, $1 S_{57}$

13. Tigress $\ldots$

$\begin{array}{llll}\cdots & \cdots & 8 & 0\end{array}$

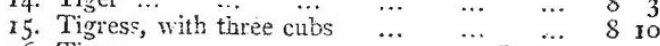

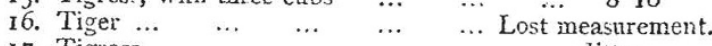

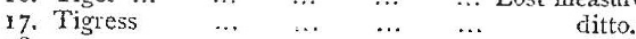

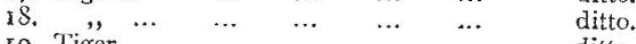
19. Tiger $\ldots \quad \ldots \quad \ldots \quad \ldots \quad \ldots$ ditto.

2o. Tiuress, very large, pulled G.'s elephant down, lost measurement.

21. Tiger killed in Hangua (drive) from a tree, very large. Waldah, Bengal, i 870

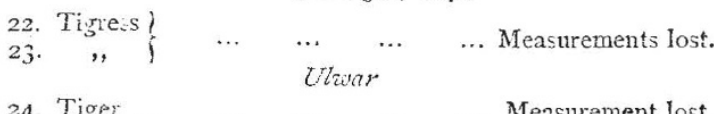
24. Tiger $\ldots \quad \ldots \quad \ldots \quad \ldots \quad$... Mensurement lost.

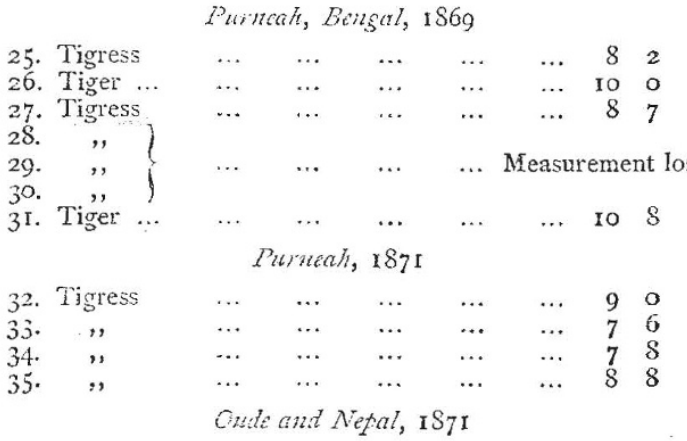

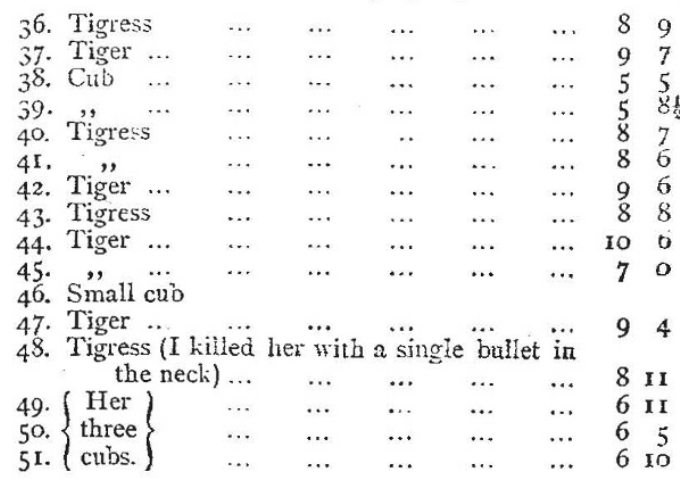

These are all the notes I can lay my hands on at present. The largest tiger was Io feet 8 inches, the largest tigress, 9 feet. Both were Bengal Purneah tigers. My own experience, therefore, confirms so much of Jerdon's estimate as that the tiger averages from 9 to $9 \frac{2}{2}$ feet, the tigress between 8 and 9 feet; but that which he and others doubt, viz., that tigers do occasionally attain the length of upwards of ro feet 3 inches and even in feet or 12 feet, and the tigress up to 10 feet or even more, is 
conclusively attested by the evidence of the gentleme whose statements I have quoted.

I am indebted to Sir Dighton Probyn for an interesting letter from Capt. Gerard, of Goona, a high authority on Indian felidx. He expresses his belief that tigers seldom if ever exceed Jerdon's measurements, a tiger of 10 feet I inch being the length of the largest he has ever killed or seen. He refers to examples of large tigers described by various observers, but he doubts the accuracy of the measurements, which he thinks may have been unintentionally exaggerated. His own experience is very large, his accuracy as an observer well known, and his opinion consequently of much value; but it is hardly sufficient to invalidate that of others who are no less competent to note and record facts, and who certainly give a greater length, as the extreme growth of the tiger, than that within which Capt. Gerard limits him. The matter then stands thus : Mr. C. Shillingford, Col. G. Boileau, and Sir C. Reid, ${ }^{1}$ vouch for tigers of over i2 feet. The same gentlemen, with Sir H. Green, Sir G. Yule, the Hon. R. Drummond, Col, D. G. Stewart, Mr. Cumming, and Col. Shakespeare vouch for tigers of II feet and upwards. The above, with Col. J. Sleeman, Sir Joseph Fayrer, Mr. B. Simson, and the Hon. Sir H. Ramsay vouch for tigers of ro feet 5 inches and upwards, all from measurements taken before the animals were skinned. Unless these gentlemen, all of whom are accustomed to shoot and measure tigers, were mistaken, the question of length may, I think, be regarded as decided beyond dispute.

In conclusion, after thanking sincerely those gentlemen who have given me information derived from their own experience, I would just say that the mere length of a tiger is not necessarily an indication of its real size. The tail is included in the measurement-so tiger hunters have ruled that it shall be-but the tail is a somewhat variable element; in some it is long, in others short, and it is quite possible that a 9 -foot 6 -inch tiger with a short tail may be heavier, stronger, and larger than a Io-foot tiger with a long tail. No doubt anything over Io feet is very large, and those of II or I2 are rare and exceptional, even though part of their great length may be assigned to an immensely long tail. But I think that, while making all allowances for errors of measurement-which doubtless are not uncommon, though unintentional--there is still sufficient evidence from accurate measurements to show that tigers may exceed Io feet 3 inches, and that a few-perhaps rare and exceptional instances-do exceed even II and iz feet.

J. FAYRER

\section{THE TELEPHONE, ITS HISTORY AND ITS RECENT IMPROVEMENTS ${ }^{1}$}

$$
\text { II. }
$$

I $\mathrm{N}$ the preceding article we traced the history and development of the magneto-telephone. This instrument, even if it served no other purpose, has given to physicists a galvanoscope of surpassing delicacy. In the columns of this journal (vol. xvii. p. 343) Prof. Forbes showed how the feeblest thermo-electric currents could be detected by its means, whilst the subsequent discovery of the microphone was but another application of the same fact. This latter instrument and the early history of the carbon telephone we now propose to consider.

In the spring of the present year Mr. W. H. Preece startled every one by announcing that Prof. Hughes, the well-known inventor of the type-printing telegraph, had discovered that a couple of bits of charcoal, or a few fragments of metal in loose contact, when in circuit with

I Since writing the above I have been informed by General Sir C. Reid, K.C. B. Bengal Army, that he has shot, and measured before the skin was removed, in the Dhoon a tiger of 12 feet 3 inches.

removed, in the Dhoon a tiger of 12 feet 3 inches. by G. B. Prescott. Illustrated. (New York, Appletons, 1878.)-"Le Ty G. B. Prescott. Hone, le Microphoue, et le Phonographe," par Le Conte Th. du Moncel. (Hachette, $1 \varepsilon_{7} 8$.) Continued from vol, xviii. p. 700 . a telephone and a voltaic cell, were able to reveal the faintest tremor or even to transmit the sound of the voice itself. Universal interest was excited by this discovery; a direct transformation of sonorous vibrations into electricity was supposed to have been discovered, but soon it became apparent that the explanation originally suggested was untenable, and that the true theory of the microphone was to be found in minute variations of current strength. The quivering of the loose fragments produced variable degrees of contact or of pressure, and the marvellous sensitiveness of the magneto-telephone revealed these otherwise inappreciable fuctuations in the resistance of the circuit.

On account of its sensitiveness, the microphone has been suggested as likely to be of use in auscultation. ${ }^{1} \mathrm{M}$. diz Moncel gives a form of stethoscopic microphone made by M. Ducretet, and shown in Fig. 2. The microphone pencil, $C$, rests upon a lower plate of carbon, $\mathrm{p}$, which is adapted to a caoutchouc capsule, $\mathrm{T}$, and this again is connected by a flexible tube to a second capsule, $T^{\prime}$, which can be applied to different parts of the body of the patient. Although the sensibility of the microphone can to some extent be regulated by the counterpoise, $P$ O, yet still the objection to this apparatus is its over sensibility, for it reveals every noise or tremor, so that it is difficult to distinguish one sound from another. It is not impossible, however, that this or some other arrangement of the microphone may ultimately be found to yield important results in the hands of a physician who has made himself skilled in its use. At the same time we must bear in mind that, after its employment in a surgical case by Sir H. Thompson, the large expectations that were formed of the microphone as an exploring instrument in surgery have not as yet been fulfilled. We are not aware whether the microphone has been tried by seismologists, or by military men to detect the mining operations of an enemy, though we should fear the same causes that operate against it elsewhere might also occur wherever it is employed. The disturbances to which the instrument is subject are most conspicuous when the microphone is used, as it can be, to transmit speech. Nevertheless a particular arrangement, designed by Mr. Hughes (Fig. 3), gives fair results. The two. fragments of carbon are shown at $C D$, the upper one being attached to a light metal arm $A$, controlled by a spring $\mathrm{R}$, the tension of which is regulated by a screw $t$. The whole is inclosed in a light wooden box $\mathrm{H}^{\prime} \mathrm{I}$ G, surrounded by a second box $M \mathrm{~J} L$, the end of which is left open. A single carbon only, may even be used, touching the metal arm, as is shown at $\mathrm{E}$. In this case the carbon is supported by a strip of paper gummed to. the bottom of the box. Loid as is the articulation transmitted by means of this arrangement, the noisy roar which accompanies it, from tremors picked up by carbons, render many words quite inaudible in the receiving telephone. So far, in fact, the microphone bas not proved a practical instrument; it seems, however, likely to become a useful adjunct in physical or physico-chemical researches. In any case science is indebted to Prof. Hughes for first making known an entirely novel, simple, and delicate instrument for the detection of minute mechanical motions.

We say first making known, for some twelve months. before Prof. Hughes published his description of the microphone, an arrangement designed by Mr. Edison was singularly like the microphone in its extreme delicacy to the minutest tremor. A couple of inches of silk ribbon rubbed with plumbago and made stiff with gum, was laid upon two metal supports joined in circuit with a telephone and a small battery. Such an arrangement not only de-

I Apropos of the microphone a literary friend sends me the following extract from an ancient Turkish tract containing an exposition of the Moslems creed:- "He (Allah) hears alike the loudest and gentlest sounds and sees all things, even the waiking in a dark night of a black ant on a black stone, wid hears the treading of its feet, and this without eyes or ears." 